\begin{tabular}{|c|c|c|}
\hline & $\begin{array}{c}\text { European Association for the } \\
\text { Development of Renewable Energies, Environment } \\
\text { and Power Quality (EA4EPQ) }\end{array}$ & $\begin{array}{l}\text { International Conference on Renewable Energies and Power Quality } \\
\text { (ICREPQ'12) } \\
\text { Santiago de Compostela (Spain), 28th to 30th March, } 2012\end{array}$ \\
\hline
\end{tabular}

\title{
Remodelling of the heating systems of a sports centre based on life cycle assessment. Part II: Solar hybrid system.
}

\author{
I. Oribe-García ${ }^{1}$, A.M. Macarulla-Arenaza ${ }^{1}$ and A. Alonso-Vicario ${ }^{1}$ \\ ${ }^{1}$ Deusto Institute of Technology - DeustoTech Energy \\ University of Deusto \\ Avda. de las Universidades 24, 48007 Bilbao (Spain) \\ Phone/Fax number:+0034 9441390 00, e-mail: iraia.oribe@deusto.es, ana.macarulla@deusto.es, \\ ainhoa.alonso@deusto.es
}

\begin{abstract}
.
The remodelling study of heating and cooling installations of the municipal sports centre of Ordizia (Spain) has been widened including a renewable energy proposal, integrating also the concept of life cycle analysis (LCA) of the installation which allows therefore, to analyze the environmental impact prior its approval and implementation.
\end{abstract}

The analysis of the inclusion of two set of solar panels (thermal and photovoltaic) in addition to the substitution of the old diesel boiler by a more efficient natural gas equipment, in order to satisfy the power demand of the installations, has been studied by means of life cycle analysis.

The supply directly from the grid is the alternative with the greatest impact, while the photovoltaic is the most efficient one from an environmental standpoint. However, when solar irradiation is insufficient for the needs of the sports centre, a hybrid system is the best choice.

In a similar way, in order to satisfy the heat demand, the combination of thermal panels with the natural gas boiler has been proven to be a good solution.

\section{Key words}

Renovation of facilities, Life Cycle Analysis (LCA), Renewable energy, Environmental impact, solar energy.

\section{Introduction}

The environmental analysis of a product or process along the whole life cycle (LCA) enables to evaluate and adopt measures in order to minimize its environmental impact. Consequently LCA is one of the most used tools for decision-making, once the environmental diagnostic has been carried out and the main consequences evaluated.

In a previous work the use of LCA during the remodelling of the heating system installations in the sports centre of Ordizia (Spain) enabled to identify the main advantages of replacing the old diesel boiler by a gas natural one since an environmental standpoint [1]. However, the use of fossil fuel has great impact, especially on the climate change, contributing also to the natural resources depletion.

The energy needs of sports facilities are summarized in Figure 1, which ranges from, electricity consumption for lighting, water pumping or air conditioning, to consumption of fossil fuels to produce hot water for heating, domestic hot water production, heating and indoor swimming pools, among others [2]. Therefore, it is considered necessary to analyze different energy supply options to achieve an optimal confort level with the minimum energy consumption and environmental impact.

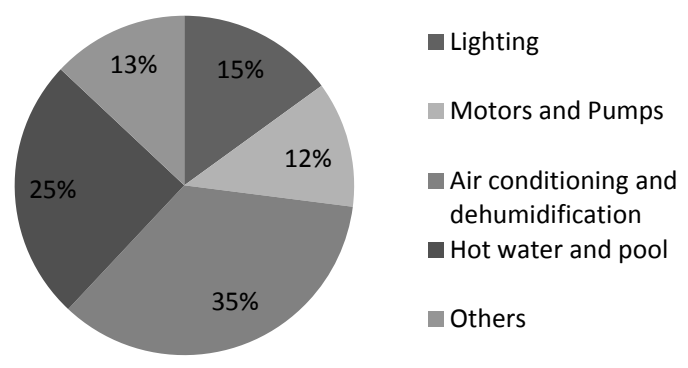

Fig 1. Distribution of energy consumption in sports facilities.

The introduction of renewable energy systems like solar panels may be a good solution. There are many previous experiences and it has even been regulated in many countries for new construction projects. This is the case of Spain, where the Technical Building Code (CTE), using the basic requirement "Energy Saving”, seeks to achieve rational use of energy in buildings, reducing the consumption to sustainable limits and also to achieve that a portion of this consumption comes from renewable energy sources [3].

CTE demands the introduction of systems including two types of solar panels in new buildings: 
- Significant solar contribution to hot water: If there is a forecast of demand for hot water or indoor climate control, part of the thermal energy requirements arising from this demand will be met by the incorporation of collection, storage and use of low-temperature solar energy systems.

- Significant photovoltaic electricity contribution.

Nevertheless, it is not clear the profit of the solar panels, specially the photovoltaic ones. Several studies concluded that the most critical phases are the transformation of silicon metal and silicon solar panel assembly itself [4].

In this work, an additional remodelling of the sport facilities which incorporates renewable energies in the heating system and DHW, and in the electrical system has been studied and evaluated. This incorporation consists of a hybrid system of solar panels: thermal and photovoltaic.

\section{Description of the scenarios}

Among the energy needs of the Ordizia sports facilities, the thermal demand of the pools is one of the most significant. Against this requirement, solar thermal energy at low temperature is presented as a good alternative. With optimal weather conditions, a solar thermal installation can cover up to $80 \%$ of the total hot water demand and $100 \%$ of the demand for indoor heated pools. However, the solar collection system can not always guarantee $100 \%$ of the required service, so that the system often needs to be combined with conventional heating systems. There are many sports facilities that already have such hybrid systems. The district sports complex in Ejido (León, Spain), has a power system that includes solar thermal $\left(198 \mathrm{~m}^{2}\right)$, biomass $(300 \mathrm{~kW})$ and natural gas $(300 \mathrm{~kW})[2]$.

Therefore, and to meet the thermal demand of the sport centre of Ordizia, it is proposed a hybrid system of solar thermal panels and natural gas boiler.

The operation principle of a solar thermal system with a gas boiler, is based on the collection of solar energy through a set of collectors and its transfer to a storage system that supplies the consumption. If the heated water has not reached the desired temperature, the natural gas boiler is used as a complement [5].

On the other hand, and in order to meet the electricity needs, it is proposed a $5 \mathrm{~kW}$ grid connected photovoltaic system (PV). An example of this system can be found in the University of Murcia in the Espinardo Campus (Murcia, Spain) [6].

To sum up, the inclusion of solar energy both in the heating system and the electrical system has been analysed. The solar system subjected to evaluation consists of a set of thermal panels of $50 \mathrm{~m}^{2}$ for the production of hot water, for both preheating water pool and the production of DHW, and a grid-connected photovoltaic one of $5 \mathrm{~kW}$.

\section{Methodology}

The LCA study has been carried out using the software SIMAPRO 7.3 (by Pré Consultants) and following the methology described in detail in the first part of this remodelling project [1]. In this case, the impact categories analyzed are depletion of natural resources and climate change.

The boundaries for the analysis of this scenario are drawn in the diagram in Figure 2, which takes into account the extraction of materials, their assembly, the operation of the system, and the dismantling.

The comparative analysis has been carried out according to power demand: electrical or heating demand, respectively. $k W h$ to meet the demand of one year has been defined as the functional unit for the scope of the study.

The inventory stage has been carried out according to the information provided by suppliers, Ecoinvent database v2.1 and literature [7-9].

\section{Results}

The study is based on the consumption data of year 2010, those from electrical energy and those from the diesel boiler and according to the characteristic solar radiation data of the geographical area.

The alternative heating system as set hybrid system proposed is composed of solar thermal panels and a natural gas boiler. Taking into account the potential of solar power in the area of Ordizia, the supposed average of use has been $60 \%$ natural gas boiler and $40 \%$ solar power [10].

The different materials used for the construction of the solar system and their proportion are listed in Table I. The solar collection system is mainly constituted with a collector, water tank and additional components (pipes, heat exchanger, pumps,...). The collector consists of an absorber with a selective coating, a covering (single glazing), an insulation, a casing, a frame and a sealing. The main absorber material is copper. Glazing materials are glass or polycarbonate, insulation materials are made out of mineral wool and foams, and the casing of aluminium.

The lifetime of the solar thermal system is assumed to be 25 years for all components. An external source of energy for the additional heat supply has also been considered in the operation phase [7]. 


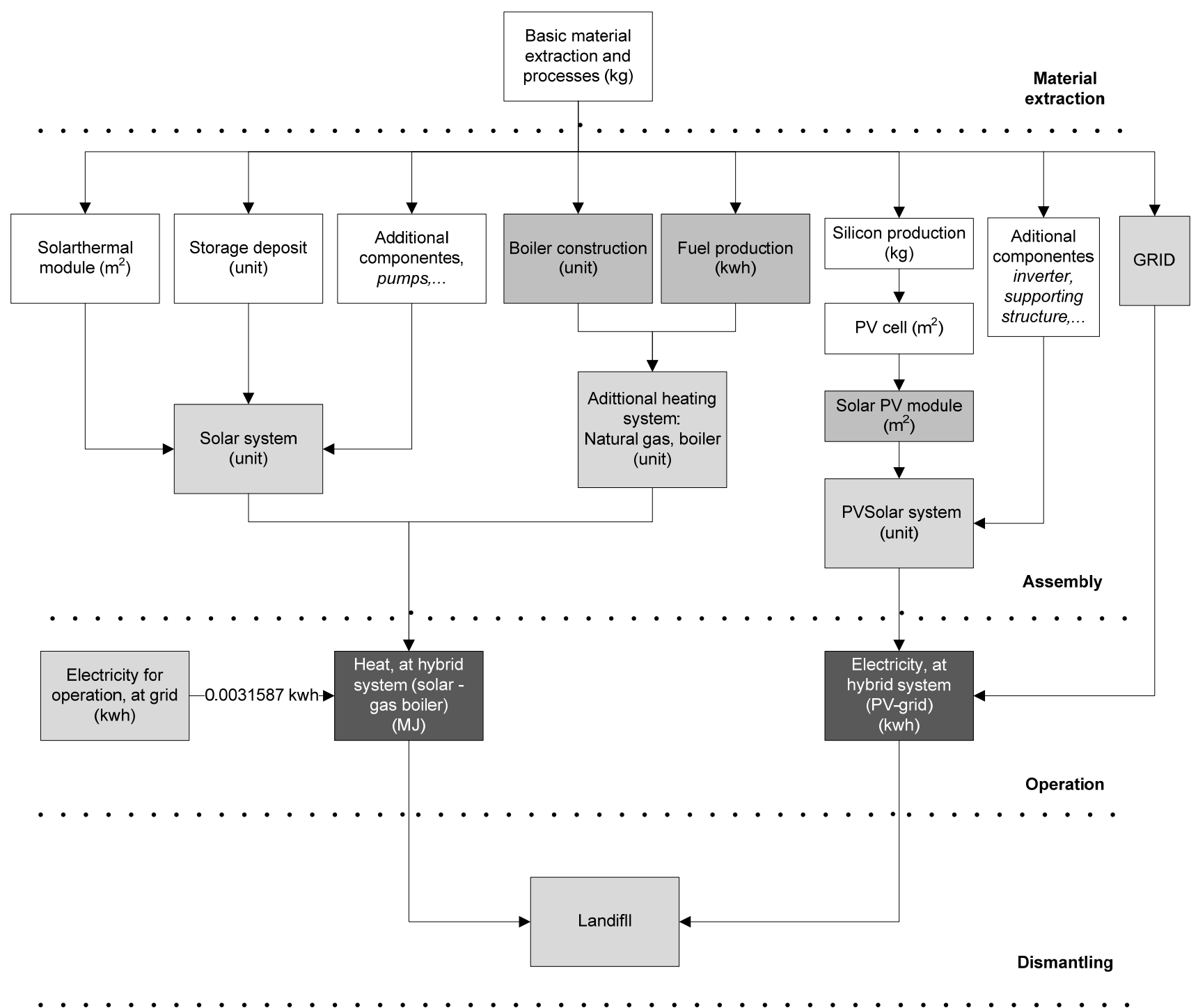

Fig. 2. LCA limits of the hybrid system.

Table I. - Employed material in the construction of $1 \mathrm{~m}^{2}$ solar thermal panel.

\begin{tabular}{|l|c|}
\hline MATERIAL & MASS (kg) \\
\hline Rock wool & 2.43 \\
\hline Corrugated board & 3.68 \\
\hline Solar glass & 9.12 \\
\hline Synthetic rubber & 0.732 \\
\hline Silicone & 0.059 \\
\hline Propylene glycol & 1.01 \\
\hline Aluminium & 3.93 \\
\hline Copper & 2.82 \\
\hline Chromium steel & 4.14 \\
\hline
\end{tabular}

Grid-connected PV are constituted with PV solar module, inverter, and supporting structures. To achieve the construction of the PV solar module its main constituent, silica, must undergo a transformation process.

Firstly, silica sand is transformed in metallurgical grade silicon. Then it is purified into electronic grade silicon (EG-Silicon). EG-silicon is molten until the Czochralski grade silicon is produced.
Before producing the solar cell, monocrystalyne columns are sawn into wafers. In the PV operation phase, there is no external source of energy supply.

Taken into account dismantling phase has been difficult, given that this type of installation began to be installed few years ago, so the majority of the installations have not reached their end-life and the information available about their recycling mechanism is not enough to model in the software.

However, it is supposed that the installations has high potential to be reused or recycled (metallic components, representing more than 80\%) [8]. Therefore, as dismantling scenario, it has chosen disposal in landfill.

According to these premises, two different analysis have been made. One, to analyze what phase has the greatest impact. And second one, to analyze in which manner the introduction of the solar energy could reduce the overall impact of the installations. 
Overall, for the only use of solar thermal, the construction phase shows the greatest impact, compared to the operation and dismantling phases.

By other hand, the construction of the solar panel shows higher impact than the construction of the boiler, $79 \%$ and $21 \%$ respectively. However, unlike the case of boilers, the impact on the operation phase is practically zero given that fuel is not consumed.

Figure 3 shows the comparison of the environmental impact (abiotic depletion and climate change categories) between the heat supply by a gas boiler and a hybrid system covered by thermal panels and a boiler in a 40/60 ratio, such as injection system in cases where solar radiation is insufficient, respectively.

It is important to note, that in the construction of the thermal panel, the construction of the collector is the phase that has the greatest impact.

Despite this, for both evaluated impact categories, the exclusive use of natural gas boiler is more harmful for the environment that a partial combination with renewable solar energy system. In fact, the both impact categories are reduced by $50 \%$.

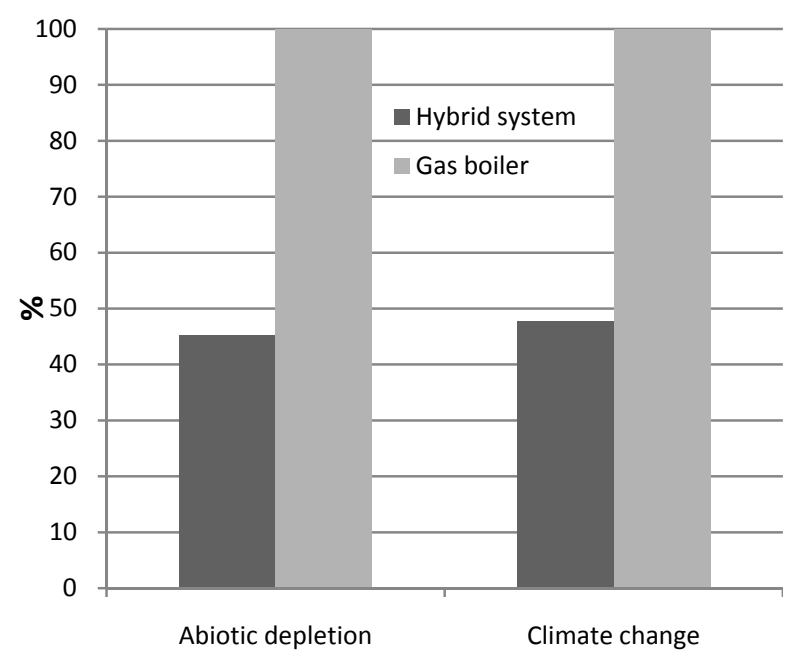

Fig. 3. Environmental impact: hybrid system (40\% solar-60\% gas boiler) and gas boiler.

The next step has been to compare the performance of the supply of power energy by means of photovoltaic panels. In this case, it is the construction of the solar panel and the inverter the process which greatest contribute to the impact of the installation. However, there is none impact in the operation phase.

Figure 4 shows the results for only power grid connection, only solar photovoltaic panels and a hybrid system (60\% grid, $40 \%$ solar).

The results obtained in this work are in full agreement with those found in the literature [11].

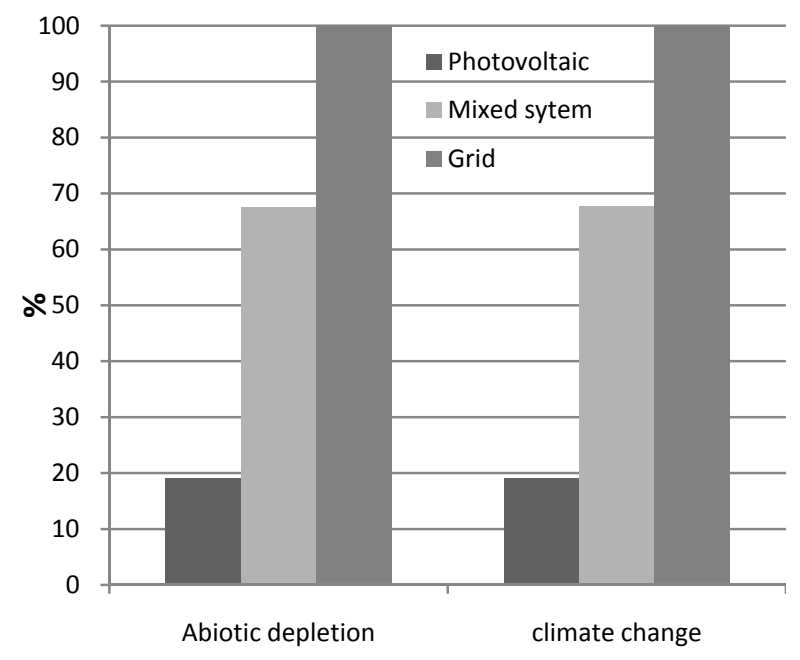

Fig. 4. Environmental impact: Grid electric energy (100\%), photovoltaic (100\%) and mixed system (60 \%-40 \%).

\section{Conclusions}

Basing the study on the impact of all systems on the use of natural resources and the production of $\mathrm{CO}_{2}$ eq. (the category known as climate change), the main conclusion is that the solar installations during the construction phase have great impact, but it is compensated during the production phase, because of the use of renewable energy versus fossil fuels. So, among the environmental benefits from the use of solar system, there are:

- Lower fuel consumption, avoiding emissions from its combustion and production.

- Lower energy dependence: diversification of energy sources.

Although in this study is mentioned that the greatest drawback from the use of solar energy systems is the construction stage, it was not the aim of the this study to perform a detailed study in that phase, focusing on the benefit of the introduction of solar energy.

Finally, note that the considered scenario was pessimistic about the phase of dismantling solar panels, so that a more detailed study of recycling components further justifies the benefits of the renovation of the heating system.

\section{Acknowledgement}

The authors express their gratitude to Ingeriketa Lantzen, S.L. for allowing us to develope and present this work. The contributions of Iñigo Goitia and Mikel González to this paper are also gratefully acknowledged.

\section{References}

[1] I. Oribe-García, A. Alonso-Vicario, A.M. MacarullaArenaza, Remodelling of the heating systems of a sports centre based on life cycle assessment. Part I: Boiler replacement, International Conference on Renewable Energies and Power Quality (ICREPQ'12), Santiago de Compostela 28-30 March, 2012. 
[2] Guía de eficiencia energética en instalaciones deportivas. Consejería de economía y consumo, Comunidad Madrid, 2008.

[3] Código Técnico de la Edificación: CTE. Available at: http://www.codigotecnico.org/web/recursos/documentos/.

[4] A. Stoppato, "Life cycle assessment of photovoltaic electricity generation”. Energy, 2008, 33, pp 224-232.

[5] Energía solar térmica y gas natural en edificios, Fundación Gas Natural, Barcelona, Spain, 2005. Available at: www.fundaciongasnatural.org

[6] R. García Valverde, C. Miguel, R. Martínez-Bejar, A. Urbina, "Life cycle assessment study of a 4,2 kwp standalone photovoltaic system". Solar energy, 2009, 83, pp 1434-1445.

[7] N. Jungbluth, "Life Cycle Inventories of Energy Systems: Solar Collector Systems”, Ecoinvent, 2007. p. 128-134.

[8] F. Ardente, G. Beccali, M. Cellura, V. Lo Brano, "Life cycle assessment of a solar thermal collector". Renewable Energy, 2005, 3, pp 1031-1054.

[9] A.F. Sherwani, J.A. Usmani, Varun, "Life cycle assessment of solar PV based electricity generation systems: A review”. Renewable and Sustainable Energy Reviews, 2010, 14, pp 540-544.

[10] PVGIS, solar irradiation data. Available at: http://re.jrc.ec.europa.eu/pvgis/apps/radmonth.php?lang=es \&map=europe.

[11] M. Raugei, P. Frankl, "Life cycle impacts and costs of photovoltaic systems: Current state of the art and future outlooks”. Energy, 2009, 34, pp 392-399. 